\title{
Parameters of Physiology, Nutrition and Quality of Eugenia dysenterica DC Seedlings Grown in Organic Substrates from the Agricultural Industry
}

\author{
C. S. Mota ${ }^{1}$, Fabiano Guimarães Silva ${ }^{2}$, Paulo Dornelles ${ }^{2}$, Mariângela Brito Freiberger ${ }^{2}$, \\ Daniele Nogueira dos Reis ${ }^{2} \&$ Giselle Camargo Mendes ${ }^{1}$ \\ ${ }^{1}$ Instituto Federal Catarinense, Rio do Sul, Brazil \\ ${ }^{2}$ Instituto Federal Goiano, Rio Verde, Brazil \\ Correspondence: Mariângela Brito Frediberger, Plant Tissue Culture Laboratory, Instituto Federal Goiano, Rio \\ Verde, GO, Rod. Sul Goiana km 01, s/n, Brazil. Tel: 55-64-98166-0156. E-mail: maia_bf@yahoo.com.br
}

Received: September 25, 2017

doi:10.5539/jas.v10n1p73
Accepted: November 4, $2017 \quad$ Online Published: December 15, 2017

URL: https://doi.org/10.5539/jas.v10n1p73

The research is financed by Coordination for the Improvement of Higher Education Personnel (CAPES).

\begin{abstract}
Residues from agricultural activities might be used as substrates for production of seedlings. In this study it was aimed to evaluate the physiology, nutrition and quality of Eugenia dysenterica DC. seedlings grown in substrates derived from agricultural organic wastes. The wastes used were as follows: rice husks (RHs); fermented cattle manure (FCM); cattle manure compost (CMC), which contained corn silage and FCM; sugarcane bagasse (SCB); filter cake from sugar-alcohol mills (FC); and subsoil (SB). Four substrates were formulated from the wastes, namely SB+RH (1:1; v:v), SB+CMC (1:1), SB+FCM (3:1) and SCB+FC (3:2) and Bioplant ${ }^{\circledR}$ substrate was also used. The following characteristics were evaluated: the emergence and vigor percentages, biometric characteristics, seedling quality indices, gas exchange, chlorophyll $a$ fluorescence and leaf nutrient levels. The seedling emergence was similar for all the substrates. The highest vigor was found in seedlings that were cultivated in $\mathrm{SCB}+\mathrm{FC}$, which was equal to the vigor observed in Bioplant ${ }^{\circledR}$. In general, the use of the $\mathrm{SB}+\mathrm{CMC}$ substrate gave better seedling results for the biometric and nutritional characteristics, followed by $\mathrm{SCB}+\mathrm{FC}$. Most of the biometric characteristics showed a correlation with photosynthesis, electron transport rate and effective quantum yield of photosystem II, thus showing that these characteristics can be alternatives to the traditional quality indexes used for seedlings. The use of CMC, SCB and FC was shown to be appropriate for the production and nutritional supply of seedlings' specie. The composition SB (subsoil)+CMC (1:1) proved to be the most suitable to produce $E$. dysenterica seedlings.
\end{abstract}

Keywords: cagaita tree, sugarcane bagasse, cattle manure, mineral nutrition, gas exchanges, Dickson quality

\section{Introduction}

The Cerrado (tropical savanna) is considered the second largest Brazilian biome and is home to a great diversity of plant species (Paiva Sobrinho et al., 2010). Eugenia dysenterica DC is a fruiting species endemic to the Cerrado, belongs to the Myrtaceae family and is popularly known as cagaita (Souza et al., 2013). Its fruit is consumed in whole form or processed into sweet and jams, and it is also used in ice creams, popsicles and beverages. This fruit is considered to be an important source of vitamins C and A (Cardoso et al., 2011). Souza et al. (2012) reported the high inhibitory activity of cagaita fruits for $\alpha$-amylase and $\alpha$-glucosidase, with the latter contributing to the control of diabetes. The extract of its leaves have shown anti-diarrheal activity, so that the plant offers promise as medication (Lima et al., 2010).

The cagaita has socioeconomic and ecological importance (Bailão et al., 2015). The cultivation of native species through seedlings propagation can be an effective way to avoid biodiversity loss in the Cerrado biome. The propagation of woody plant species is achieved by producing high quality seedlings; that is, healthy, well-nourished and robust plants. These characteristics contribute to the survival of plants after transplantation to the field, thus resulting in the success of orchard installations, even in reforesting situations (Gomes et al., 2003). 
The starting point for obtaining quality seedlings can be the use of substrate combinations with appropriate chemical and physical characteristics, organic matter and water contents which will provide the best conditions for development, according to species necessities (Boene et al., 2013). The good substrate, to favor germination and emergence, must exhibit porosity degrees that allows seed hydratation and aeration, since at the beginning it mainly requires water and oxygen for their germination and emergence (Nogueira et al., 2003); must exhibit slow decomposition, has a high cation-exchange capacity, and be free from pathogens and seeds of undesired plants (Dantas et al., 2009). The substrates derived from organic waste of agricultural industries can present these characteristics and represent cost reduction for farmers, also being a sustainable way of allocating waste from milling processes. To obtain these characteristics is often necessary mix two or more components, which together will form a suitable substrate for seedlings formation (Araújo Neto et al., 2009).

Dornelles et al. (2014) studied the development of Anacardium othonianum Rizz seedlings (Cerrado cashew tree) in substrates formulated with Mecplant ${ }^{\circ}(\mathrm{MP})+$ carbonized rice husk (CRH) in 7:1 (v:v proportion), fine-grained vermiculite (FGV), FGV+CRH (3:1), FGV+CRH (1:1), FGV+CRH (1:3), and sugarcane bagasse (SB) + sugarcane mill filter cake (FC) (3:2). They verified that the substrate SB+FC (3:2) promoted the best nutrition for plants. Mota et al. (2016a) concluded that the use of cattle manure mixed with subsoil in 1:3 proportion (v:v), provided the best results for the biometric characteristics and dry matter production of Pouteria gardneriana (Cerrado's native plant, popularly called guapeva).

The quality indices that are used to evaluate the seedlings are ratios, such as the one between shoot height and diameter, root and shoot dry weights (DWs) and other possible ratios that indicate seedlings robustness. Dickson et al. (1960) created a quality index that considers the ratios mentioned above as well as the accumulation of total DWs. Analyses of physiological parameters (Mota et al., 2016b) and nutritional status (Mota et al., 2016a) has been used to complement the growth and development parameters of native Cerrado seedlings. However, there are few studies that evaluate the production of seedlings based on all these parameters. Thus, the objective of this study was to evaluate the growth, quality, nutrition, gas exchange and fluorescence of chlorophyll $a$ in $E$. dysenterica seedlings produced in substrates formulated with organic wastes from agricultural industries inferring about their use on Cerrado reforestation areas.

\section{Method}

\subsection{Plant Material}

The Eugenia dysenterica DC fruits were harvested from healthy adult plants, in full production, at Gameleira Farm located in Montes Claros de Goiás, GO, Brazil (19 $53^{\prime} \mathrm{S}$ latitude, $44^{\circ} 25^{\prime} \mathrm{W}$ longitude, altitude of $749 \mathrm{~m}$ ). The fruits were transported to the Laboratory of Plant Tissue Culturing (LCTV) of the Goiano Federal Institute -

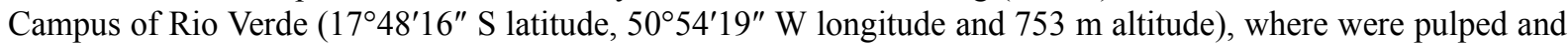
the seed coats were removed to facilitate germination (Martinotto et al., 2007). The study was conducted in a greenhouse at the LCTV. Temperature and relative humidity inside the greenhouse were recorded using a DataLogger (NOVUS, Porto Alegre, Brazil) being the average values of temperature and relative humidity of $25.5^{\circ} \mathrm{C}$ and $76 \%$, respectively.

\subsection{Chemical Properties of Substrates}

The tested substrates were formulated from sugarcane bagasse (SCB), filter cake from sugar-alcohol mills (FC), fermented cattle manure (FCM), rice husks (RHs), cattle manure compost (CMC) (which contained corn silage and FCM), subsoil (SB) from a soil classified as Distroferric Red Latosol and the commercial substrate Bioplant ${ }^{\circledR}$. According to information from the manufacturer, this last substrate is composed of Pinus bark, vermiculite, coir, aggregating agents and mineral supplements (NPK+micro). Five substrates were formulated and tested as follows: Bioplant ${ }^{\circledR}, \mathrm{SCB}+\mathrm{FC}$ at a $3: 2$ proportion $(3: 2), \mathrm{SB}+\mathrm{RH}(1: 1), \mathrm{SB}+\mathrm{CMC}(1: 1)$ and $\mathrm{SB}+\mathrm{FCM}$ (3:1) whose chemical characteristics are shown in Table 1. 
Table 1. Chemical analysis of macro and micronutrients of the substrates used in the study

\begin{tabular}{|c|c|c|c|c|c|c|c|c|c|c|c|c|c|}
\hline Substrate & $\mathrm{pH}$ & $\mathrm{OM}$ & $\mathrm{Ca}$ & $\mathrm{Mg}$ & CEC & $\mathrm{V}$ & $\mathrm{K}$ & $\mathrm{P}$ & $\mathrm{Fe}$ & $\mathrm{Mn}$ & $\mathrm{Cu}$ & $\mathrm{Zn}$ & $\mathrm{B}$ \\
\hline & $\mathrm{H}_{2} \mathrm{O}$ & $\mathrm{gkg}^{-1}$ & ------- & $\mathrm{mg} \mathrm{dm}^{-3}$ & ------- & $\%$ & $-\ldots$ & $-\cdots$ & -a--- & $\mathrm{gg} \mathrm{dm}$ & & & \\
\hline Bioplant ${ }^{\circledR}$ & 4.97 & 430 & 10.4 & 4.04 & 18.7 & 56 & 1207 & 3.7 & 132 & 52 & 1.66 & 24.5 & 2.14 \\
\hline $\mathrm{SB}^{\mathrm{y}}+\mathrm{RH}^{\mathrm{x}}(1: 1)$ & 6.42 & 22 & 1.1 & 0.37 & 2.6 & 55 & 3.3 & 20.8 & 39 & 24 & 1.76 & 3.8 & 0.17 \\
\hline $\mathrm{SB}+\mathrm{CMC}^{\mathrm{w}}(1: 1)$ & 6.60 & 118 & 4.3 & 6.90 & 12.6 & 86 & 950 & 170 & 103 & 62 & 2.33 & 22.6 & 0.56 \\
\hline $\mathrm{SB}+\mathrm{FCM}^{\mathrm{v}}(3: 1)$ & 6.40 & 25 & 3.6 & 3.5 & 8.5 & 82 & 543 & 82.3 & 58 & 35 & 4.75 & 17.2 & 0.53 \\
\hline $\mathrm{SCB}^{\mathrm{u}}+\mathrm{FC}^{\mathrm{t}}(3: 2)$ & 7.02 & 600 & 2.3 & 0.61 & 5.3 & 70 & 667 & 21.9 & 153 & 81 & 2.32 & 30.8 & 2.29 \\
\hline
\end{tabular}

Note. ${ }^{\mathrm{y}}$ Subsoil; ${ }^{\mathrm{x}}$ Rice husks; ${ }^{\mathrm{w}}$ Cattle manure compost (corn silage + fermented cattle manure); ${ }^{\mathrm{v}}$ Fermented cattle manure; " Sugarcane bagasse; ${ }^{\mathrm{t}}$ Filter cake from sugar-alcohol mill; ${ }^{\mathrm{s}}$ Base saturation index; ${ }^{\mathrm{r}}$ Organic matter; and ${ }^{\mathrm{q}}$ Effective cation exchange capacity.

\subsection{Seedling Growth and Morphological Characteristics}

Containers (tubes) of $288 \mathrm{~cm}^{3}$ were filled with the substrates, and one seed was sown in each container. The spray irrigation was $12 \mathrm{~mm}$ day $^{-1}$, divided into two irrigations diary. Percent seedling emergence (PSE) was tested at two day intervals between emergence of the first seedling and the end of emergence; the emergence speed index (ESI) was calculated according to Maguire (1962).

After 128 days of seeding, were measured stem diameter (SD) and count the number of seedlings leaves (NL), which were separated in stems, leaves, and roots. The stem length (SL) and the leaf area (LA) was obtained. The stems, leaves, and roots were dried in a forced-air oven at $65{ }^{\circ} \mathrm{C}$ to constant weight, to obtain weights separately. The ratio between the SL and SD (SL/SD), the ratio between the root dry weight and shoot dry weight (R/S), and the Dickson quality index (DQI) were used as seedling quality parameters according to Dickson et al. (1960). Leaves from the plants of each replicate were combined and ground in a Willey mill to determine the micro and macronutrient content on nutrients according to Malavolta et al. (1997).

\subsection{Physiological Measurements}

Seedling gas exchange, fluorescence, growth, quality, and water content, as well as substrate moisture content, were evaluated at 128 days after the seeding. Gas exchange was evaluated in the morning between 7:30 and 11:30 am with an LCi portable photosynthesis meter (ADC BioScientific, Great Amwell, United Kingdom), that generated the following variables: net $\mathrm{CO}_{2}$ assimilation $(A)$, transpiration $(E)$, water use efficiency $(A / E)$ obtained from the ratio between $A$ and $E$, and stomatal conductance $\left(g_{s}\right)$. The chlorophyll $a$ fluorescence variables were obtained using a Mini-PAM modulated fluorometer (Walz, Effeltrich, Germany). The maximum quantum yield of photosystem II (PSII) $\left(\mathrm{F}_{\mathrm{v}} / \mathrm{F}_{\mathrm{m}}\right)$ was calculated using the darkness parameters with the equation, $\mathrm{F}_{\mathrm{v}} / \mathrm{F}_{\mathrm{m}}=\left(\mathrm{F}_{\mathrm{m}}-\mathrm{F}_{0}\right) / \mathrm{F}_{\mathrm{m}}$, where $\mathrm{F}_{0}$ and $\mathrm{F}_{\mathrm{m}}$ are the minimum and maximum fluorescence, respectively, of the dark-adapted plant tissue obtained before dawn. $\mathrm{F}_{0}$ was obtained by lighting the plant tissue with a low-intensity modulated red light $\left(0.03 \mu \mathrm{mol} \mathrm{m} \mathrm{m}^{-2}\right)$, and $\mathrm{F}_{\mathrm{m}}$ was obtained with a saturating light pulse $\left(6,000 \mu \mathrm{mol} \mathrm{m} \mathrm{m}^{-2}\right)$ lasting 0.8 seconds. The effective quantum yield of PSII $(\phi P S I I)$ was calculated using the equation $\phi P S I I=\left(\mathrm{F}_{\mathrm{m}}\right.$, $-\mathrm{F}) / \mathrm{F}_{\mathrm{m}}$ ', on what $\mathrm{F}_{\mathrm{m}}$ ' and $\mathrm{F}$ are the maximum fluorescence and fluorescence, respectively, when the plant tissue is under actinic light with an intensity of $1,000 \mu \mathrm{mol} \mathrm{m} \mathrm{m}^{-2} \mathrm{~s}^{-1}$ for 50 seconds. The quantum yield of regulated non-photochemical energy dissipation of PSII ( $\phi N P Q)$ and the quantum yield of unregulated non-photochemical energy dissipation of PSII ( $\phi \mathrm{NO})$ were obtained according to Hendrickson et al. (2004). The apparent electron transport rate of PSII (ETR) was obtained from Bilger et al. (1995).

The relative water content (RWC) and substrate moisture content were measured before dawn at 4:30 am. To determine RWC, one leaf was collected per plant using a scalpel and was then immediately weighed on an analytical balance to obtain the fresh weight $(\mathrm{FW})$. After obtaining the $\mathrm{FW}$, the leaves were placed in a humid chamber, and the petioles were immersed in distilled water, remaining under these conditions for 24 hours at $25^{\circ} \mathrm{C}$, with compensation irradiance, to allow the leaves to reach maximum turgor. After the leaves reached maximum turgor, they were weighed to obtain the turgid weight (TW) and were then dried in a forced-air oven at $65{ }^{\circ} \mathrm{C}$ to constant weight, yielding the dry weight (DW). The RWC was calculated using the equation RWC $=(\mathrm{FW}-$ $\mathrm{DW}) /(\mathrm{TW}-\mathrm{DW})$. To determine the relative moisture of the substrates studied, substrate samples were collected from the same tube containing the plants used for determining the RWC. Immediately after collecting the substrates, they were weighed on a semi-analytical balance to obtain wet weight (WW) and then dried in a forced-air oven at $105{ }^{\circ} \mathrm{C}$ to constant weight, yielding the substrate dry weight (DW). To obtain the relative moisture content of the substrate (WCDS) on a dry basis, the equation WCDS $=(\mathrm{WW}-\mathrm{DW}) / \mathrm{DW}$ was used. 


\subsection{Experimental Design and Statistical Analysis}

The experiment followed a randomized block design with five replicates and 20 tubes per replicate for PSE and ESI, two for RWC and WCDC, one for gas exchange and fluorescence, and five for the other evaluations. The data were subjected to an analysis of variance and Tukey test. A significance level of $5 \%$ was used to discriminate the minimal significant differences among the means. For the correlations analysis, Pearson's Method was used. The statistical analysis was performed using the computational program SAEG 9.1.

\section{Results}

The ability of the substrates to absorb water differed among the substrates. The water content was greatest in the $\mathrm{SCB}+\mathrm{FC}$, followed by the others in the following order: Bioplant ${ }^{\mathbb{B}}>\mathrm{SB}+\mathrm{CMC}>\mathrm{SB}+\mathrm{RH}$, and the substrate $\mathrm{SB}+\mathrm{FCM}$ did not differ from the last two items (Table 2). Despite the difference in the water contents of the substrates, this characteristic did not influence the RWC of the E. dysenterica seedlings. The PES, which had a mean value of $97.2 \%$, was not influenced by the tested substrates (Table 3 ). The cagaita tree seedlings had greater vigor when grown in the Bioplant ${ }^{\circledR}$ and $\mathrm{SCB}+\mathrm{FC}$ substrates, followed by the $\mathrm{SB}+\mathrm{FCM}$ and $\mathrm{SB}+\mathrm{RH}$ substrates. Less vigor was observed in the $\mathrm{SB}+\mathrm{CMC}$ treatment.

The gas exchange characteristics of the E. dysenterica seedlings, such as the liquid assimilation of $\mathrm{CO}_{2}(A)$, transpiration $(E)$, stomatal conductance $\left(g_{s}\right)$, and the ratio between the intercellular and atmospheric concentration $(\mathrm{Ci} / \mathrm{Ca})$, did not differ in accordance with the tested substrates (Table 4). The mean values of $A, E$, $g_{s}$ and $C i / C a$ were $6.31 \mu \mathrm{mol} \mathrm{m}^{-2} \mathrm{~s}^{-1}, 2.23 \mathrm{mmol} \mathrm{m}^{-2} \mathrm{~s}^{-1}, 0.16 \mathrm{~mol} \mathrm{~m}^{-2} \mathrm{~s}^{-1}$ and $0.69 \mathrm{~mol} \mathrm{~mol}{ }^{-1}$, respectively.

Table 2. Water content in the dry base substrates (WCDS) and leaf relative water content (RWC) in Eugenia dysenterica DC. seedlings grown in different substrates

\begin{tabular}{|c|c|c|}
\hline Substrate & WCDS & RWC \\
\hline & \multicolumn{2}{|c|}{ 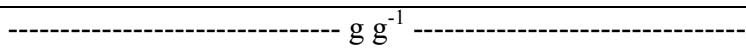 } \\
\hline Bioplant $^{\circledR}$ & $1.73 b^{\mathrm{z}}$ & $0.95^{\mathrm{ns}}$ \\
\hline $\mathrm{SB}^{\mathrm{y}}+\mathrm{RH}^{\mathrm{x}}(1: 1)$ & $0.35 \mathrm{~d}$ & 0.96 \\
\hline $\mathrm{SB}+\mathrm{CMC}^{\mathrm{w}}(1: 1)$ & $0.60 \mathrm{c}$ & 0.96 \\
\hline $\mathrm{SB}+\mathrm{FCM}^{\mathrm{v}}(3: 1)$ & $0.51 \mathrm{~cd}$ & 0.93 \\
\hline $\mathrm{SCB}^{\mathrm{u}}+\mathrm{FC}^{\mathrm{t}}(3: 2)$ & $2.22 \mathrm{a}$ & 0.96 \\
\hline $\mathrm{MSD}^{\mathrm{s}}$ & 0.205 & 0.064 \\
\hline
\end{tabular}

Note. ${ }^{\mathrm{z}}$ Means followed by the same letter do not differ from one another according to Tukey's test ( $\left.\mathrm{p}<0.05\right)$; ${ }^{\mathrm{y}}$ Subsoil; ${ }^{\mathrm{x}}$ Rice husks; ${ }^{\mathrm{w}}$ Cattle manure compost (Corn silage + fermented cattle manure); ${ }^{\mathrm{v}}$ Fermented cattle manure; "Sugarcane bagasse; ${ }^{\mathrm{t}}$ Filter cake from sugar-alcohol mill; ${ }^{\mathrm{s}}$ Minimum significant difference; and ${ }^{\mathrm{ns}}$ Non-significant difference.

Table 3. Percentage of emerged seedlings (PES) and emergence speed index (ESI) in Eugenia dysenterica DC. seedlings cultivated in different substrates

\begin{tabular}{lll}
\hline Substrate & PES & ESI \\
\hline & $\%$ & - \\
Bioplant $^{\circledR}$ & $98^{\mathrm{ns}}$ & $0.36 \mathrm{a}^{\mathrm{z}}$ \\
$\mathrm{SB}^{\mathrm{y}}+\mathrm{RH}^{\mathrm{x}}(1: 1)$ & 98 & $0.29 \mathrm{~b}$ \\
$\mathrm{SB}+\mathrm{CMC}^{\mathrm{w}}(1: 1)$ & 92 & $0.23 \mathrm{c}$ \\
$\mathrm{SB}+\mathrm{FCM}^{\mathrm{v}}(3: 1)$ & 98 & $0.30 \mathrm{~b}$ \\
$\mathrm{SCB}^{\mathrm{u}}+\mathrm{FC}^{\mathrm{t}}(3: 2)$ & 100 & $0.35 \mathrm{a}$ \\
\hdashline $\mathrm{MSD}^{\mathrm{s}}$ & 9.88 & 0.044 \\
\hline
\end{tabular}

Note. ${ }^{\mathrm{z}}$ Means followed by the same letter do not differ from one another according to Tukey's test ( $\left.\mathrm{p}<0.05\right)$; ${ }^{\mathrm{y}}$ Subsoil; ${ }^{\mathrm{x}}$ Rice husks; ${ }^{\mathrm{w}}$ Cattle manure compost (Corn silage + fermented cattle manure); ${ }^{\mathrm{v}}$ Fermented cattle manure; "Sugarcane bagasse; ${ }^{\mathrm{t}}$ Filter cake from sugar-alcohol mill; ${ }^{\mathrm{s}}$ Minimum significant difference; and ${ }^{\mathrm{ns}}$ Non-significant difference. 
Table 4. Rate of liquid assimilation for $\mathrm{CO}_{2}(A)$, transpiration $(E)$, stomatal conductance $\left(g_{s}\right)$ and the ratio between intercellular and atmospheric concentrations $(\mathrm{Ci} / \mathrm{Ca})$ in Eugenia dysenterica $\mathrm{DC}$. seedlings cultivated in different substrates

\begin{tabular}{lllll}
\hline Substrate & $A$ & $E$ & $g_{s}$ & $C i / C a$ \\
\hline & $\mu \mathrm{mol} \mathrm{m}^{-2} \mathrm{~s}^{-1}$ & $\mathrm{mmol} \mathrm{m}^{-2} \mathrm{~s}^{-1}$ & $\mathrm{~mol} \mathrm{~m}^{-2} \mathrm{~s}^{-1}$ & $\mathrm{~mol} \mathrm{~mol}^{-1}$ \\
Bioplant $^{\circledR}$ & $5.34^{\mathrm{ns}}$ & $2.06^{\mathrm{ns}}$ & $0.14^{\mathrm{ns}}$ & $0.72^{\mathrm{ns}}$ \\
$\mathrm{SB}^{\mathrm{y}}+\mathrm{RH}^{\mathrm{x}}(1: 1)$ & 4.02 & 1.56 & 0.09 & 0.71 \\
$\mathrm{SB}+\mathrm{CMC}^{\mathrm{w}}(1: 1)$ & 7.79 & 2.39 & 0.17 & 0.65 \\
$\mathrm{SB}+\mathrm{FCM}^{\mathrm{v}}(3: 1)$ & 7.15 & 2.65 & 0.23 & 0.69 \\
$\mathrm{SCB}^{\mathrm{u}}+\mathrm{FC}^{\mathrm{t}}(3: 2)$ & 7.23 & 2.48 & 0.18 & 0.68 \\
$\mathrm{MSD}^{\mathrm{s}}$ & 4.50 & 1.94 & 0.187 & 0.105 \\
\hline
\end{tabular}

Note. ${ }^{\mathrm{z}}$ Means followed by the same letter do not differ from one another according to Tukey's test ( $\left.\mathrm{p}<0.05\right)$; ${ }^{\mathrm{y}}$ Subsoil; ${ }^{\mathrm{x}}$ Rice husks; ${ }^{\mathrm{w}}$ Cattle manure compost (Corn silage + fermented cattle manure); ${ }^{\mathrm{v}}$ Fermented cattle manure; "Sugarcane bagasse; ${ }^{\mathrm{t}}$ Filter cake from sugar-alcohol mill; ${ }^{\mathrm{s}}$ Minimum significant difference; and ${ }^{\mathrm{ns}}$ Non-significant difference.

The characteristics of chlorophyll $a$ fluorescence in the E. dysenterica DC. seedlings, as indicated by the minimum fluorescence adapted to the dark $\left(\mathrm{F}_{0}\right)$, maximum quantum yield of the PSII $\left(\mathrm{F}_{\mathrm{v}} / \mathrm{F}_{\mathrm{m}}\right)$ and effective quantum yield of the PSII ( $\phi$ PSII), were not influenced by the tested substrates (Table 5). Their means were 212, 0.76 and 0.28 , respectively. The ETR differed in two of the tested substrates; it was higher in plants that were cultivated in the SCB+FC substrate and lower in the SB+RH substrate, with means of 140.7 and $75.5 \mu \mathrm{mol} \mathrm{m}$ $\mathrm{s}^{-1}$, respectively.

Table 5. Minimum fluorescence adapted to the dark $\left(\mathrm{F}_{0}\right)$, maximum quantum yield of the PSII $\left(\mathrm{F}_{\mathrm{v}} / \mathrm{F}_{\mathrm{m}}\right)$, effective quantum yield of the PSII ( $\phi$ PSII) and electron transport rate (ETR) in Eugenia dysenterica DC. seedlings cultivated in different substrates

\begin{tabular}{lllll}
\hline Substrate & $\mathrm{F}_{0}$ & $\mathrm{~F}_{\mathrm{v}} / \mathrm{F}_{\mathrm{m}}$ & $\phi$ PSII & $\mathrm{ETR}$ \\
\hline & - & - & - & $\mu \mathrm{mol} \mathrm{m}^{-2} \mathrm{~s}^{-1}$ \\
Bioplant $^{\circledR}$ & $209.4^{\mathrm{ns}}$ & $0.76^{\mathrm{ns}}$ & $0.23^{\mathrm{ns}}$ & $90.90 \mathrm{ab}^{\mathrm{z}}$ \\
$\mathrm{SB}^{\mathrm{y}}+\mathrm{RH}^{\mathrm{x}}(1: 1)$ & 219.8 & 0.74 & 0.20 & $75.45 \mathrm{~b}$ \\
$\mathrm{SB}+\mathrm{CMC}^{\mathrm{w}}(1: 1)$ & 205.8 & 0.78 & 0.33 & $125.13 \mathrm{ab}$ \\
$\mathrm{SB}+\mathrm{FCM}^{\mathrm{v}}(3: 1)$ & 221.6 & 0.74 & 0.32 & $123.58 \mathrm{ab}$ \\
$\mathrm{SCB}^{\mathrm{u}}+\mathrm{FC}^{\mathrm{t}}(3: 2)$ & 203.4 & 0.78 & 0.34 & $140.65 \mathrm{a}$ \\
$\mathrm{MSD}^{\mathrm{s}}$ & 25.68 & 0.043 & 0.154 & 59.54
\end{tabular}

Note. ${ }^{\mathrm{z}}$ Means followed by the same letter do not differ from one another according to Tukey's test $(\mathrm{p}<0.05)$; ${ }^{\mathrm{y}}$ Subsoil; ${ }^{\mathrm{x}}$ Rice husks; ${ }^{\mathrm{w}}$ Cattle manure compost (Corn silage + fermented cattle manure); ${ }^{\mathrm{v}}$ Fermented cattle manure; "Sugarcane bagasse; ${ }^{\mathrm{t}}$ Filter cake from sugar-alcohol mill; ${ }^{\mathrm{s}}$ Minimum significant difference; and ${ }^{\mathrm{ns}}$ Non-significant difference.

The cultivation substrates had an influence on all the biometric characteristics that were evaluated in the $E$. dysenterica seedlings (Table 6). The SB+CMC substrate gave the seedlings highest values in all of the biometric characteristics, except for the DW of the roots (DWR), which had lower values than those of the Bioplant ${ }^{\circledR}$ substrate. In relation to the evaluated biometric characteristics, the seedlings cultivated in the SCB+FC substrate did not differ from those grown in the SB+CMC substrate. For the biometric characteristics, the lowest values were observed in the seedlings that were grown in the SB+RH substrate, except for the total dry weight (TDW), which showed no difference in the other substrates; and the dry weight of the roots (DWR), which was greater than that of the SB+FCM and less than that of the Bioplant ${ }^{\circledR}$. Similar to the $\mathrm{SB}+\mathrm{RH}$, the latter substrate provided the cultivated seedlings with the lowest values for the biometric characteristics, except for the DWR, which was greater than that of the others, and the TDW, which was greater than that of the SB+FCM substrate. 
Table 6. Stem length (SL), root collar diameter (RCD), number of leaves (NL), dry weight of stem (DWS), dry weight of leaves (DWL), dry weight of roots (DWR) and total dry weight (TDW) in Eugenia dysenterica DC. seedlings cultivated in different substrates

\begin{tabular}{|c|c|c|c|c|c|c|c|}
\hline Substrate & $\mathrm{SL}$ & $\mathrm{RCD}$ & $\mathrm{NL}$ & DWS & DWL & DWR & TDW \\
\hline & $\mathrm{cm}$ & $\mathrm{mm}$ & ---- & ------ & --- g --- & --------- & ------------ \\
\hline Bioplant ${ }^{\circledR}$ & $3.04 c^{z}$ & $0.98 \mathrm{c}$ & $2.08 \mathrm{~b}$ & $0.020 \mathrm{~b}$ & $0.145 \mathrm{~cd}$ & $0.599 \mathrm{a}$ & $0.765 \mathrm{a}$ \\
\hline $\mathrm{SB}^{\mathrm{y}}+\mathrm{RH}^{\mathrm{x}}(1: 1)$ & $3.02 \mathrm{c}$ & $0.95 \mathrm{c}$ & $2.44 \mathrm{~b}$ & $0.018 \mathrm{~b}$ & $0.129 \mathrm{~d}$ & $0.466 \mathrm{~b}$ & $0.613 \mathrm{ab}$ \\
\hline $\mathrm{SB}+\mathrm{CMC}^{\mathrm{w}}(1: 1)$ & $5.21 \mathrm{a}$ & $1.26 \mathrm{ab}$ & $5.04 \mathrm{a}$ & $0.038 \mathrm{a}$ & $0.348 \mathrm{a}$ & $0.367 \mathrm{bc}$ & $0.753 \mathrm{ab}$ \\
\hline $\mathrm{SB}+\mathrm{FCM}^{\mathrm{v}}(3: 1)$ & $3.96 \mathrm{bc}$ & $1.33 \mathrm{a}$ & $3.88 \mathrm{a}$ & $0.037 \mathrm{a}$ & $0.226 \mathrm{bc}$ & $0.339 \mathrm{c}$ & $0.602 \mathrm{~b}$ \\
\hline $\mathrm{SCB}^{\mathrm{u}}+\mathrm{FC}^{\mathrm{t}}(3: 2)$ & $4.96 \mathrm{ab}$ & $1.13 \mathrm{~b}$ & $4.76 \mathrm{a}$ & $0.041 \mathrm{a}$ & $0.272 \mathrm{ab}$ & $0.404 \mathrm{bc}$ & $0.716 \mathrm{a}$ \\
\hline $\mathrm{MSD}^{\mathrm{s}}$ & 1.17 & 0.15 & 1.20 & 0.0095 & 0.084 & 0.110 & 0.16 \\
\hline
\end{tabular}

Note. ${ }^{\mathrm{z}}$ Means followed by the same letter do not differ from one another according to Tukey's test ( $\left.\mathrm{p}<0.05\right)$; ${ }^{\mathrm{y}}$ Subsoil; ${ }^{\mathrm{x}}$ Rice husks; ${ }^{\mathrm{w}}$ Cattle manure compost (Corn silage + fermented cattle manure); ${ }^{\mathrm{v}}$ Fermented cattle manure; "Sugarcane bagasse; ${ }^{\mathrm{t}}$ Filter cake from sugar-alcohol mill; ${ }^{\mathrm{s}}$ Minimum significant difference; and ${ }^{\mathrm{ns}}$ Non-significant difference.

Most of the biometric characteristics evaluated in the E. dysenterica seedlings showed a correlation with the gas exchanges and chlorophyll $a$ fluorescence (Table 7). The SL, NL, dry weight of the stems (DWS) and dry weight of the leaves (DWL) showed a positive correlation with the $A, \phi$ PSII and ETR. The $\mathrm{F}_{\mathrm{v}} / \mathrm{F}_{\mathrm{m}}$ showed a positive correlation with the biometric characteristics of SL, NL, DWL and the TDW. The latter characteristic also showed a negative correlation with the $\mathrm{F}_{0}$. Of the three quality indices evaluated (DQI, R/S and SL/RCD), the $\mathrm{SL} / \mathrm{RCD}$ showed a positive correlation with $A, \mathrm{~F}_{\mathrm{v}} / \mathrm{F}_{\mathrm{m}}, \phi \mathrm{PSII}$ and ETR and a negative correlation with $\mathrm{F}_{0}$. The $\mathrm{R} / \mathrm{S}$ ratio showed a negative correlation with $\phi$ PSII and ETR. The DQI did not have a correlation with the gas exchanges or chlorophyll $a$ fluorescence (Table 7).

Table 7. Matrix of Pearson's linear correlation between the characteristics of gas exchange and chlorophyll $a$ fluorescence and the biometric characteristics and quality of Eugenia dysenterica DC. seedlings grown in different substrates

\begin{tabular}{lllllllll}
\hline & $A^{\mathrm{z}}$ & $E^{\mathrm{y}}$ & $g_{s}{ }^{\mathrm{x}}$ & $C i / C a^{\mathrm{w}}$ & $\mathrm{F}_{0}{ }^{\mathrm{v}}$ & $\mathrm{F}_{\mathrm{v}} / \mathrm{F}_{\mathrm{m}}{ }^{\mathrm{u}}$ & $\phi \mathrm{PSII}^{\mathrm{t}}$ & $\mathrm{ETR}^{\mathrm{s}}$ \\
\hline $\mathrm{SL}^{\mathrm{r}}$ & $0.452^{*}$ & 0.303 & 0.255 & -0.264 & -0.332 & $0.491^{*}$ & $0.548^{*}$ & $0.529^{*}$ \\
$\mathrm{RCD}^{\mathrm{q}}$ & 0.212 & 0.074 & 0.100 & -0.386 & 0.249 & -0.077 & 0.322 & 0.326 \\
$\mathrm{NL}^{\mathrm{p}}$ & $0.530^{*}$ & 0.399 & 0.382 & -0.187 & -0.351 & $0.524^{*}$ & $0.632^{*}$ & $0.593^{*}$ \\
$\mathrm{DWS}^{\mathrm{o}}$ & $0.444^{*}$ & 0.317 & 0.313 & -0.246 & -0.151 & 0.323 & $0.527^{*}$ & $0.519^{*}$ \\
$\mathrm{DWL}^{\mathrm{n}}$ & $0.436^{*}$ & 0.277 & 0.240 & -0.326 & -0.272 & $0.482^{*}$ & $0.511^{*}$ & $0.487^{*}$ \\
$\mathrm{DWR}^{\mathrm{m}}$ & -0.156 & -0.080 & -0.162 & 0.167 & -0.205 & 0.076 & -0.225 & -0.231 \\
$\mathrm{TDW}^{1}$ & 0.228 & 0.169 & 0.051 & -0.108 & $-0.453^{*}$ & $0.501^{*}$ & 0.223 & 0.196 \\
$\mathrm{SL}^{\mathrm{R} C \mathrm{RD}^{\mathrm{k}}}$ & $0.409^{*}$ & 0.310 & 0.232 & -0.105 & $-0.559^{*}$ & $0.616^{*}$ & $0.437^{*}$ & $0.418^{*}$ \\
$\mathrm{R}_{\mathrm{S}}^{\mathrm{j}}$ & -0.346 & -0.212 & -0.235 & 0.346 & 0.024 & -0.194 & $-0.410^{*}$ & $-0.429^{*}$ \\
$\mathrm{DQI}^{\mathrm{i}}$ & -0.253 & -0.156 & -0.214 & 0.110 & 0.055 & -0.128 & -0.296 & -0.285 \\
\hline
\end{tabular}

Note. *Significant Pearson's correlation at the $5 \%$ probability level; ${ }^{\mathrm{z}}$ Liquid assimilation of $\mathrm{CO}_{2} ;{ }^{\mathrm{y}}$ Transpiration; ${ }^{\mathrm{x}}$ Stomatal conductance; ${ }^{\mathrm{w}} \mathrm{Ci} / \mathrm{Ca}$ ratio; ${ }^{\mathrm{v}}$ Minimum fluorescence adapted to the dark; ${ }^{\mathrm{u}}$ Maximum quantum yield of the PSII; ${ }^{\mathrm{t}}$ Effective quantum yield of the PSII; ${ }^{\mathrm{s}}$ Electron transport rate; ${ }^{\mathrm{r}}$ Stem length; ${ }^{\mathrm{q}}$ Root collar diameter; ${ }^{\mathrm{p}}$ Number of leaves; ${ }^{\circ}$ Dry weight of stem; ${ }^{\mathrm{n}}$ Dry weight of leaves; ${ }^{\mathrm{m}}$ Dry weight of roots; ${ }^{\mathrm{l}}$ Total dry weight; ${ }^{\mathrm{k}} \mathrm{Ratio}$ between length and diameter of stem; ${ }^{j}$ Ratio between dry weight of the shoot and the root system; and ${ }^{\mathrm{i}}$ Dickson quality index.

The DQI was higher in plants cultivated in the Bioplant ${ }^{\mathbb{B}}$ substrate than in plants cultivated in the $\mathrm{SB}+\mathrm{CMC}$, $\mathrm{SB}+\mathrm{FCM}$ and $\mathrm{SCB}+\mathrm{FC}$ substrates (Table 8). In relation to the other substrates, the Bioplant ${ }^{\circledR}$ and the $\mathrm{SB}+\mathrm{RH}$ substrate provided the seedlings that were cultivated in them with a higher ratio between the dry weight of the root system and the shoot $(\mathrm{R} / \mathrm{S})$. The $\mathrm{SL} / \mathrm{RCD}$ was greater in the seedlings cultivated in the $\mathrm{SCB}+\mathrm{FC}$ and $\mathrm{SB}+\mathrm{CMC}$ substrates than in those cultivated in the other substrates. 
Table 8. Ratio between stem length and root collar diameter (SL/RCD) and between the dry weights of the roots and shoots $(\mathrm{R} / \mathrm{S})$ as well as the Dickson quality index (DQI) in Eugenia dysenterica DC. seedlings grown in different substrates

\begin{tabular}{llll}
\hline Substrate & $\mathrm{SL} / \mathrm{RCD}$ & $\mathrm{R} / \mathrm{S}$ & $\mathrm{DQI}$ \\
\hline & $\mathrm{cm} \mathrm{mm}^{-1}$ & $\mathrm{~g} \mathrm{~g}^{-1}$ & - \\
Bioplant $^{\circledR}$ & $3.12 \mathrm{~b}^{\mathrm{z}}$ & $3.80 \mathrm{a}$ & $0.23 \mathrm{a}$ \\
$\mathrm{SB}^{\mathrm{y}}+\mathrm{RH}^{\mathrm{x}}(1: 1)$ & $3.18 \mathrm{~b}$ & $3.34 \mathrm{a}$ & $0.19 \mathrm{ab}$ \\
$\mathrm{SB}+\mathrm{CMC}^{\mathrm{w}}(1: 1)$ & $4.11 \mathrm{a}$ & $1.16 \mathrm{~b}$ & $0.15 \mathrm{~b}$ \\
$\mathrm{SB}+\mathrm{FCM}^{\mathrm{v}}(3: 1)$ & $3.03 \mathrm{~b}$ & $1.44 \mathrm{~b}$ & $0.17 \mathrm{~b}$ \\
$\mathrm{SCB}^{\mathrm{u}}+\mathrm{FC}^{\mathrm{t}}(3: 2)$ & $4.42 \mathrm{a}$ & $1.59 \mathrm{~b}$ & $0.15 \mathrm{~b}$ \\
MSD $^{\mathrm{s}}$ & 0.91 & 0.74 & 0.05 \\
\hline
\end{tabular}

Note. ${ }^{\mathrm{z}}$ Means followed by the same letter do not differ from one another according to Tukey's test ( $\left.\mathrm{p}<0.05\right)$; ${ }^{\mathrm{y}}$ Subsoil; ${ }^{\mathrm{x}}$ Rice husks; ${ }^{\mathrm{w}}$ Cattle manure compost (Corn silage + fermented cattle manure); ${ }^{\mathrm{v}}$ Fermented cattle manure; "Sugarcane bagasse; ${ }^{\mathrm{t}}$ Filter cake from sugar-alcohol mill; ${ }^{\mathrm{s}}$ Minimum significant difference; and ${ }^{\mathrm{ns}}$ Non-significant difference.

The highest leaf nitrogen $(\mathrm{N})$ levels were provided by the SB+CMC and SCB+FC substrates (the SCB+FC value did not differ from that of the SB+FCM), while the lowest leaf $\mathrm{N}$ levels were observed in the Bioplant ${ }^{\circledR}$ and $\mathrm{SB}+\mathrm{RH}$ substrates (Table 9). For phosphorous (P), the Bioplant ${ }^{\mathbb{B}}$ and $\mathrm{SCB}+\mathrm{FC}$ substrates provided the highest leaf concentrations in relation to the other substrates. In the $\mathrm{SB}+\mathrm{RH}$ substrate, the leaf $\mathrm{P}$ concentration was lower than the others were and did not differ from the SB+CMC; the latter did not differ from the SB+FCM substrate. The leaf potassium $(\mathrm{K})$ concentrations were highest in the Bioplant ${ }^{\circledR}$ and $\mathrm{SB}+\mathrm{RH}$ substrates. The latter showed no difference in relation to the $\mathrm{SB}+\mathrm{CMC}$ and $\mathrm{SB}+\mathrm{FCM}$ substrates, and these two were similar to the $\mathrm{SCB}+\mathrm{FC}$, which in turn had a lower concentration than the first two.

Table 9. Levels of macro and micronutrients in the leaf tissue of Eugenia dysenterica DC. seedlings cultivated in different substrates

\begin{tabular}{|c|c|c|c|c|c|c|c|c|c|c|c|}
\hline Substrate & $\mathrm{N}$ & $\mathrm{P}$ & $\mathrm{K}$ & $\mathrm{Ca}$ & $\mathrm{Mg}$ & $\mathrm{S}$ & B & $\mathrm{Fe}$ & $\mathrm{Cu}$ & $\mathrm{Mn}$ & $\mathrm{Zn}$ \\
\hline & \multicolumn{6}{|c|}{ 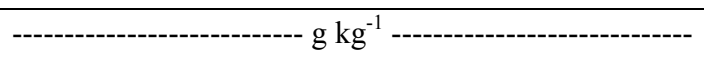 } & \multicolumn{5}{|c|}{--------------------- $\mathrm{mg} \mathrm{kg}^{-1}$--------------------- } \\
\hline Bioplant $^{\circledR}$ & $19.0 \mathrm{c}^{\mathrm{z}}$ & $5.28 \mathrm{a}$ & $13.76 \mathrm{a}$ & $10.78 b$ & $2.98 b$ & $1.02 \mathrm{a}$ & $171.2 \mathrm{a}$ & $162.8^{\mathrm{ns}}$ & $5.2^{\mathrm{ns}}$ & $67.8 \mathrm{~b}$ & $16.2^{\mathrm{ns}}$ \\
\hline $\mathrm{SB}^{\mathrm{y}}+\mathrm{RH}^{\mathrm{x}}(1: 1)$ & $15.6 \mathrm{~d}$ & $0.88 \mathrm{c}$ & $10.24 \mathrm{ab}$ & $11.12 b$ & $3.10 \mathrm{~b}$ & $0.24 b$ & $129.4 \mathrm{c}$ & 168.4 & 5.0 & $53.4 \mathrm{~b}$ & 11.8 \\
\hline $\mathrm{SB}+\mathrm{CMC}^{\mathrm{w}}(1: 1)$ & $26.4 \mathrm{a}$ & $1.92 \mathrm{bc}$ & $7.04 \mathrm{bc}$ & $25.68 \mathrm{a}$ & $7.04 \mathrm{a}$ & $1.06 \mathrm{a}$ & $138.4 \mathrm{~b}$ & 164.0 & 4.8 & $38.4 \mathrm{~b}$ & 12.6 \\
\hline $\mathrm{SB}+\mathrm{FCM}^{\mathrm{v}}(3: 1)$ & $24.4 b$ & $2.80 \mathrm{~b}$ & $9.44 b c$ & $14.82 b$ & $7.56 a$ & $1.32 \mathrm{a}$ & $122.6 \mathrm{~d}$ & 165.0 & 4.0 & $30.2 b$ & 12.8 \\
\hline $\mathrm{SCB}^{\mathrm{u}}+\mathrm{FC}^{\mathrm{t}}(3: 2)$ & $26.0 \mathrm{ab}$ & $4.24 \mathrm{a}$ & $5.92 \mathrm{c}$ & $35.98 \mathrm{a}$ & $6.98 \mathrm{a}$ & $1.18 \mathrm{a}$ & $106.4 \mathrm{e}$ & 121.8 & 5.0 & $170.8 \mathrm{a}$ & 17.6 \\
\hline $\mathrm{MSD}^{\mathrm{s}}$ & 1.95 & 1.35 & 4.04 & 10.32 & 2.12 & 0.33 & 4.83 & 80.12 & 1.23 & 42.50 & 7.00 \\
\hline
\end{tabular}

Note. ${ }^{\mathrm{z}}$ Means followed by the same letter do not differ between one another according to Tukey's test $(\mathrm{p}<0.05)$; ${ }^{\mathrm{y}}$ Subsoil; ${ }^{\mathrm{x}}$ Rice husks; ${ }^{\mathrm{w}}$ Cattle manure compost (Corn silage + fermented cattle manure); ${ }^{\mathrm{v}}$ Fermented cattle manure; "Sugarcane bagasse; ${ }^{\mathrm{t}}$ Filter cake from sugar-alcohol mill; ${ }^{\mathrm{s}}$ Minimum significant difference; and ${ }^{\mathrm{ns}}$ Non-significant difference.

Compared to the other substrates, there were higher leaf levels of calcium $(\mathrm{Ca})$ in seedlings cultivated in the $\mathrm{SCB}+\mathrm{FC}$ and $\mathrm{SB}+\mathrm{CMC}$ substrates. In relation to the other substrates, the foliar magnesium $(\mathrm{Mg})$ levels were lower in the plants cultivated in the Bioplant ${ }^{\circledR}$ and $\mathrm{SB}+\mathrm{RH}$ substrates; the leaf sulfur $(\mathrm{S})$ concentration was lower in the seedlings cultivated in the $\mathrm{SB}+\mathrm{RH}$ substrate. The $\mathrm{SCB}+\mathrm{FC}$ substrate provided the highest leaf concentration of manganese $(\mathrm{Mn})$. For boron $(\mathrm{B})$, the leaf concentrations were different in all of the substrates (which are arranged in descending order) as follows: Bioplant ${ }^{\circledR}>\mathrm{SB}+\mathrm{CMC}>\mathrm{SB}+\mathrm{RH}>\mathrm{SB}+\mathrm{FCM}>\mathrm{SCB}+\mathrm{FC}$. In the E. dysenterica seedlings, the leaf concentrations of iron $(\mathrm{Fe})$, copper $(\mathrm{Cu})$ and zinc $(\mathrm{Zn})$ were not influenced by the tested substrates.

The analyses of correlations between the leaf nutrient levels and the biometric characteristics and seedling quality show that $\mathrm{N}$ had the highest number of correlations with the following characteristics (Table 10): positive 
for SL, RCD, NL, DWS, DWL and SL/RCD; negative for DWR, R/S and DQI; and there was no correlation for TDW. After $\mathrm{N}$, the other elements that had the highest number of correlations were $\mathrm{K}$ and $\mathrm{Mg}$. $\mathrm{K}$ had a positive correlation with DWR, R/S and DQI, and a negative correlation with SL, NL, DWS, DWL and SL/RCD. Mg had a positive correlation with SL, RCD, NL, DWS, DWL and SL/RCD. The leaf Ca levels had a negative correlation with the quality indices of R/S and DQI, and a positive correlation with SL, NL, DWS, DWL and $\mathrm{SL} / \mathrm{RCD}$. The S levels generally had positive correlations (with SL, RCD, NL, DWS and DWL), but there was one negative correlation (with $\mathrm{R} / \mathrm{S}$ ).

Of the micronutrients, B had the highest number of correlations, which included negative correlations with SL, NL and DWS and positive correlations with DWR, R/S and DQI. After B, Cu had the highest number of correlations; the only negative ones were with RCD, NL and DWS. The nutrients $\mathrm{P}, \mathrm{Mn}$ and $\mathrm{Zn}$ had a correlation with DWR, SL/RCD and TDW, respectively, while Fe displayed no correlations.

Table 10. Matrix of the Pearson's linear correlation between the leaf mineral levels and the biometric characteristics and quality of Eugenia dysenterica DC. seedlings according to different substrates

\begin{tabular}{|c|c|c|c|c|c|c|c|c|c|c|c|}
\hline & $\mathrm{N}$ & $\mathrm{P}$ & $\mathrm{K}$ & $\mathrm{Ca}$ & $\mathrm{Mg}$ & $\mathrm{S}$ & B & $\mathrm{Cu}$ & $\mathrm{Fe}$ & $\mathrm{Mn}$ & $\mathrm{Zn}$ \\
\hline $\mathrm{SL}^{\mathrm{z}}$ & $0.736^{*}$ & -0.025 & $-0.638^{*}$ & $0.685^{*}$ & $0.641 *$ & $0.467^{*}$ & $-0.442 *$ & -0.342 & -0.085 & 0.286 & 0.193 \\
\hline $\mathrm{RCD}^{\mathrm{y}}$ & $0.670 *$ & -0.034 & -0.342 & 0.369 & $0.805^{*}$ & $0.599 *$ & -0.331 & $-0.502 *$ & 0.229 & -0.162 & 0.157 \\
\hline$N L^{x}$ & $0.724^{*}$ & -0.095 & $-0.715^{*}$ & $0.576^{*}$ & $0.621^{*}$ & $0.444^{*}$ & $-0.519^{*}$ & $-0.447 *$ & -0.221 & 0.209 & 0.032 \\
\hline DWS $^{\mathrm{w}}$ & $0.772 *$ & 0.088 & $-0.626^{*}$ & $0.601 *$ & $0.724 *$ & $0.592 *$ & $-0.522 *$ & $-0.404 *$ & -0.093 & 0.229 & 0.202 \\
\hline $\mathrm{DWL}^{\mathrm{v}}$ & $0.781 *$ & -0.060 & $-0.665^{*}$ & $0.572 *$ & $0.638^{*}$ & $0.476^{*}$ & -0.339 & -0.286 & -0.126 & 0.096 & 0.086 \\
\hline $\mathrm{DWR}^{\mathrm{u}}$ & $-0.580^{*}$ & $0.406^{*}$ & $0.570 *$ & -0.391 & $-0.705^{*}$ & -0.170 & $0.603 *$ & 0.275 & 0.132 & 0.088 & 0.371 \\
\hline $\mathrm{TDW}^{\mathrm{t}}$ & 0.083 & 0.396 & 0.014 & 0.100 & -0.169 & 0.259 & 0.321 & 0.023 & 0.031 & 0.195 & $0.487 *$ \\
\hline $\mathrm{SL} / \mathrm{RCD}^{\mathrm{s}}$ & $0.502 *$ & 0.036 & $-0.582 *$ & $0.667^{*}$ & 0.321 & 0.212 & -0.382 & -0.114 & -0.259 & $0.518^{*}$ & 0.188 \\
\hline $\mathrm{R} / \mathrm{S}^{\mathrm{r}}$ & $-0.841^{*}$ & 0.192 & $0.686^{*}$ & $-0.595^{*}$ & $-0.851 *$ & $-0.458^{*}$ & $0.607^{*}$ & 0.345 & 0.100 & -0.044 & 0.044 \\
\hline $\mathrm{DQI}^{\mathrm{q}}$ & $-0.579 *$ & 0.394 & $0.629 *$ & $-0.507 *$ & $-0.618 *$ & -0.080 & $0.604^{*}$ & 0.229 & 0.211 & -0.095 & 0.373 \\
\hline
\end{tabular}

Note. *Significant Pearson's correlation at the 5\% probability level; ${ }^{ }$Stem length; ${ }^{\mathrm{y}}$ Root collar diameter; ${ }^{\mathrm{x}}$ Number of leaves; ${ }^{\mathrm{w}}$ Dry weight of stem; ${ }^{\mathrm{v}}$ Dry weight of leaves; ${ }^{\mathrm{u}}$ Dry weight of roots; ${ }^{\mathrm{t}}$ Total dry weight; ${ }^{\mathrm{s}}$ Ratio between length and diameter of stem; ${ }^{\mathrm{r}}$ Ratio between dry weight of the root system and the shoot; and ${ }^{\mathrm{q}} \mathrm{Dickson}$ quality index.

\section{Discussion}

The Bioplant ${ }^{\circledR}$ and SCB+FC substrates, which had the highest water content values, also had the highest levels of organic matter (Table 1). Organic matter is a component that contributes to water absorption, and among its benefits are improvements to the soil structure. The presence of subsoil in the substrates contributed to a reduction in the water content, together with the fact that the substrates had low levels of organic matter in relation to the Bioplant ${ }^{\circledR}$ and $\mathrm{SCB}+\mathrm{FC}$. Another component that influences the water absorption capacity comprises RHs. The substrate containing this material had the lowest RWC. According to Guerrini \& Trigueiro (2004), the increase in the RH content in the substrates was inversely proportional to the water retention capacity in the same substrates. The lack of difference in the RWC in the E. dysenterica DC leaves shows that, despite the difference in the RWC in the substrates, they were able to satisfy the water requirements of the plants.

The positive correlation between the emergence speed index (ESI) of the seedlings and the water content in the substrates indicates that the amount of water absorbed by the substrate influenced the seedling vigor. The ESI found in the present study were higher than those found by Nietsche et al. (2004) of 0.08 and 0.1 for small and large cagaita seeds grown in different substrates, respectively. However, those authors did not report removing the coats from the seeds, a procedure that is believed to reduce the time to germination and emergence. In the present study, the seed coat was removed by scarification to overcome the suposed native seed dormancy. The percentage of emerged cagaita plants (PSE) was higher than observed by Souza et al. (2001), who reported $80.6 \%$. Martinotto et al. (2007) reported that the removal of the integuments from the E. dysenterica seeds favored in vitro germination, reaching close to $90 \%$.

As observed for the RWC, the evaluated substrates did not have an influence on gas exchange, and even variations in the water contents of the substrates were not enough to influence the $\mathrm{A}, \mathrm{E}, \mathrm{g}_{s}$ and $\mathrm{Ci} / \mathrm{Ca}$. Lemos-Filho (2000) reported $g_{s}$ values of $0.26 \mathrm{~mol} \mathrm{~m}^{-2} \mathrm{~s}^{-1}$ during the wet season, which are higher than those 
observed in the present study. The value closest to the one observed by the author was provided by the SB+FCM substrate $\left(0.23 \mathrm{~mol} \mathrm{~m}^{-2} \mathrm{~s}^{-1}\right)$. Neves et al. (2009) observed an $A$ value of $12 \mu \mathrm{mol} \mathrm{m}^{-2} \mathrm{~s}^{-1}$ and an $E$ of $1.2 \mathrm{mmol} \mathrm{m}^{-2}$ $\mathrm{s}^{-1}$ in Eugenia uniflora plants that were cultivated hydroponically. In comparison to the values reported in the present study, the A values were higher and the $\mathrm{E}$ values and $\mathrm{Ci} / \mathrm{Ca}$ were lower than those reported by Neves et al. (2009) for E. uniflora. The lack of difference between the $\mathrm{F}_{\mathrm{v}} / \mathrm{F}_{\mathrm{m}}$ mean values in the present study and the similarity with the values observed (0.78) by Lemos-Filho (2000) do not indicate evidence of damage in the photochemical phase. The differences between the ETR values of the plants grown in the SCB+FC and SB+RH substrates may have contributed to the difference in the photosynthesis values between them, although the result was not significantly different. Lemos-Filho (2000) found an ETR value of $200 \mu \mathrm{mol} \mathrm{m} \mathrm{m}^{-2}$, while in the present study, the ETR was no more than $140 \mu \mathrm{mol} \mathrm{m}^{-2} \mathrm{~s}^{-1}$.

The length and diameter stem growth as well as the NL, and consequently the higher values for the dry weights of the stems and leaves, were favored by the substrates containing CMC, SCB and FC in relation to the RH component and Bioplant ${ }^{\circledR}$. By contrast, the growth of the root system was greater in the Bioplant ${ }^{\circledR}$, and it was influenced by the greater accumulation of the DWR. Morgado et al. (2009) found superior biometric characteristics when using $\mathrm{SCB}+\mathrm{FC}$, regardless of the ratio between them, during the production of sugarcane seedlings. The use of cattle manure has also shown good results in species such as Acacia sp. (Cunha et al., 2006), Enterolobium contortisiliquum (Araújo \& Paiva Sobrinho, 2011) and Harconia speciosa (Silva et al., 2009); and E. dysenterica seedlings grown in combined substrates in the presence of cattle manure have shown better values for $A, E, g s, \mathrm{Fv} / \mathrm{Fm}$ and ETR as well as better biometric characteristics (Mota et al., 2016a). However, in the present study, cattle manure was more promising when it was composted with corn silage.

Despite $A$ not being influenced by the tested substrates, it was the only gas exchange characteristic to show a correlation with most of the biometric characteristics, and all were positive. The positive correlations between the biometric characteristics and the chlorophyll $a$ fluorescence characteristics, which are linked to the photosynthetic potential with ETR, $\phi$ PSII and $\mathrm{Fv} / \mathrm{Fm}$, together with $A$, demonstrate that the alterations of these characteristics influence the growth of the $E$. dysenterica seedlings.

In the analysis of the seedling quality indices, the Bioplant ${ }^{\circledR}$ substrate was observed to be associated with higher values for these indices, which suggests better quality and a better chance of survival after transplant to the field, given that it had the highest DQI and R/S and the lowest SL/RCD. The higher R/S shows that the plants invested photoassimilates into root system growth. According to Hunt (1990), the DQI for conifer seedlings should be greater than 0.20; values higher than this level were observed only for seedlings that were grown in Bioplant $t^{\mathbb{B}}$. The lower SL/RCD indicates that the seedlings that were grown in the Bioplant ${ }^{\circledR}$ substrate are robust and less likely to suffer from etiolation. The correlation between SL/RCD and $A$ as well as with the chlorophyll $a$ fluorescence characteristics demonstrates that these values can be used to evaluate the quality of $E$ dysenterica seedlings, especially fluorescence due to its status as a quick and simple evaluation method. The correlation between R/S, $\phi$ PSII and ETR also contributed to this method, strengthening the use of chlorophyll $a$ fluorescence.

However, when analyzing SL/RCD to account for the NL and the plant height, the seedlings grown in the Bioplant ${ }^{\circledR}$ only had two leaves, while those grown in $\mathrm{SB}+\mathrm{CMC}$ and $\mathrm{SCB}+\mathrm{FC}$ had approximately five leaves. If we consider that $E$. dysenterica has two opposite leaves per node (Silveira et al., 2013), the plants show one node in the Bioplant ${ }^{\mathbb{B}}$ substrate and three nodes in $\mathrm{SB}+\mathrm{CMC}$ and $\mathrm{SCB}+\mathrm{FC}$. In addition, the seedlings grown in the Bioplan $\mathrm{t}^{\circledR}$ have a height close to $60 \%$ of the height of those grown, for example, in $\mathrm{SB}+\mathrm{CMC}$, which produced the greatest height in absolute terms. If we also calculate the NL per centimeter of stem, we have 0.7 leaves $/ \mathrm{cm}$ for plants grown in Bioplant ${ }^{\mathbb{B}}$, while for the SB+CMC and SCB+FC substrates, which had higher SL/RCD values, we find 1 leaf $/ \mathrm{cm}$, thus confirming that these latter substrates were not responsible for etiolation in the seedlings. A similar characteristic occurs in the $\mathrm{R} / \mathrm{S}$, given that Bioplant ${ }^{\circledR}$ provided 3.8 times greater accumulation of dry weight in the root system than in the shoot, considering that the species prioritizes the development of the root system to the detriment of the shoot when young (Silveira et al., 2013).

Once the $\mathrm{SCB}+\mathrm{FC}$ and $\mathrm{SB}+\mathrm{CMC}$ substrates showed high leaf nutrient levels such as $\mathrm{N}, \mathrm{Ca}, \mathrm{Mg}, \mathrm{S}$ as well as $\mathrm{P}$ and $\mathrm{Mn}$ in the case of the previous, a larger NL and greater height and better equilibrium in the distribution of photoassimilates and growth of the shoot, these substrates had the capacity to meet the nutritional needs of the plants more efficiently than the Bioplant ${ }^{\circledR}$ and $\mathrm{SB}+\mathrm{RH}$ substrates. However, the correlations between the leaf nutrient levels and the biometric characteristics show that the nutrients $\mathrm{N}, \mathrm{Ca}, \mathrm{Mg}$ and $\mathrm{S}$ were the most limiting for the growth of the E. dysenterica plants. By contrast, when the foliar levels of the nutrients $\mathrm{K}, \mathrm{B}$ and $\mathrm{Cu}$ increased, there were reductions in plant growth. 
The foliar levels of $\mathrm{N}, \mathrm{Mg}$ and $\mathrm{S}$ of 15,3 and $0.4 \mathrm{~g} \mathrm{~kg}^{-1}$, respectively, that were found by Melo \& Haridasan (2009) in E. dysenterica plants are less than the levels observed in the present study, regardless of the treatment. In the comparison between the leaf macronutrient levels found by those authors and those for the plants grown in the $\mathrm{SCB}+\mathrm{FC}$ and $\mathrm{SB}+\mathrm{CMC}$ substrates, the levels are lower, except for the $\mathrm{K}$ level in the $\mathrm{SCB}+\mathrm{FC}$ substrate. The superior performance of the $E$. dysenterica plants in the $\mathrm{SCB}+\mathrm{FC}$ and $\mathrm{SB}+\mathrm{CMC}$ substrates may be related to the mineralization of the sources of organic matter.

The influence of the leaf nutrient levels on the quality indices given by the positive and negative correlations, although they were not clearly defined and, despite the effect of the nutritional levels found here (especially when they were individualized) on the quality of the seedlings, demonstrates the importance of proper nutrition for obtaining quality seedlings.

\section{Conclusion}

The use of cattle manure compost (CMC), sugarcane bagasse (SCB) and filter cake from sugar-alcohol mills (FC) have shown to be appropriate for the production and nutritional supply of $E$. dysenterica seedlings. In general, the composition SB (subsoil) + CMC (1:1) proved to be the most suitable substrate for production of $E$. dysenterica seedlings also improving seedlings success in the field allowing its use on reforesting situations.

\section{References}

Araújo Neto, S. E., Azevedo, J. M. A., Galvão, R. O., Oliveira, E. B. L., \& Ferreira, R. L. F. (2009). Produção de muda orgânica de pimentão com diferentes substratos. Ciência Rural, 39(5), 1408-1413. https://doi.org/ $10.1590 / \mathrm{S} 0103-84782009005000099$

Araújo, A. P., \& Paiva Sobrinho, S. (2011). Germinação e produção de mudas de tamboril (Enterolobium contostisiliquum (Vell.) Morong) em diferentes substratos. Revista Árvore, 35(3), 581-588. https://doi.org/ 10.1590/S0100-67622011000400001

Bailão, E., Devilla, I., Conceição, E., \& Borges, L. (2015). Bioactive compounds found in Brazilian Cerrado fruits. International Journal of Molecular Sciences, 16(10), 23760-23783. https://doi.org/10.3390/ ijms 161023760

Bilger, W., Schreiber, U., \& Bock, M. (1995). Determination of the quantum efficiency of photosystem II and of non-photochemical quenching of chlorophyll fluorescence in the field. Oecologia, 102, 425-432. https://doi.org/10.1007/BF00341354

Boene, H. C. A. M., Nogueira, A. C., Souza, N. J., Kratz, D., \& Souza, P. V. D. (2013). Efeitos de diferentes substratos na produção de mudas de Sebastiania commersoniana. Floresta, 43(3), 407-420. https://doi.org/ 10.5380/rf.v43i3.25789

Cardoso, L. M., Martino, H. S. D., Moreira, A. V. B., Ribeiro, S. M. R., \& Pinheiro Santana, H. M. (2011). Cagaita (Eugenia dysenterica DC.) of the Cerrado of Minas Gerais, Brasil: Physical and chemical characterization, carotenoids and vitamins. Food Research International, 44(1), 2151-5154. https://doi.org/ 10.1016/j.foodres.2011.03.005

Cunha, A. M., Cunha, G. M., Sarmento, R. A., \& Amaral, J. F. T. (2006). Efeito de diferentes substratos sobre o desenvolvimento de mudas de Acacia sp. Revista Árvore, 30(2), 207-214. https://doi.org/10.1590/ S0100-67622006000200007

Dantas, B. F., Lopes, A. P., Silva, F. F. S., Lúcio, A. L., Batista, P. F., Pires, M. M. M. L., \& Aragão, C. A. (2009). Taxas de crescimento de mudas de catingueira submetidas a diferentes substratos e sombreamentos. Revista Árvore, 33(3), 413-423. https://doi.org/10.1590/S0100-67622009000300003

Dickson, A., Leaf, A. L., \& Hosner, J. F. (1960). Quality appraisal of white spruce and white pine seedling stock in nurseries. Forestry Chronicle, 36(1), 10-13. https://doi.org/10.5558/tfc36010-1

Dornelles, P., Silva, F. G., Mota, C. S., \& Santana, J. G. (2014). Production and quality of Anacardium othonianum Rizz. seedlings grown in different substrates. Revista Brasileira de Fruticultura, 36(2), 479-486. https://doi.org/10.1590/0100-2945-144/13

Gomes, J. M., Couto, L., Leite, H. G., Xavier, A., \& Garcia, S. L. R. (2003). Crescimento de mudas de Eucalyptus grandis em diferentes tamanhos de tubetes e fertilização NPK. Revista Árvore, 27(2), 113-127. https://doi.org/10.1590/S0100-67622003000200001 
Guerrini, I. A., \& Trigueiro, R. M. (2004). Atributos físicos e químicos de substratos compostos por biossólido e casca de arroz carbonizada. Revista Brasileira de Ciência do Solo, 28(1), 1069-1076. https://doi.org/ 10.1590/S0100-06832004000600016

Hendrickson, L., Furbank, R. T., \& Chow, W. S. (2004). A simple alternative approach to assessing the fate of absorbed light energy using chlorophyll fluorescence. Photosynthesis Research, 82(1), 73-81. https://doi.org/10.1023/B:PRES.0000040446.87305.f4

Hunt, A. A. (1990). Effect of Styroblock Design and Copper Treatment on Morphology of Conifer Seedlings. Target seedling symposium, meeting of the western forest nursery associations, general technical report rm-200 (pp. 218-222). Roseburg. Proceedings... Fort Collins: United States Departament of Agriculture, Forest Service.

Lemos-Filho, J. P. (2000). Fotoinibição em três espécies do cerrado (Annona crassifólia, Eugenia dysenterica e Campomanesia adamantium) na estação seca e na chuvosa. Revista Brasileira de Botânica, 23(1), 45-50. https://doi.org/10.1590/S0100-84042000000100005

Lima, T. B., Silva, O. N., Oliveira, J. T. A., Vasconcelos, I. M., Scalabrin, F. B., Rocha, T. L., ... Franco, O. L. (2010). Identification of E. dysenterica laxative peptide: A novel strategy in the treatment of chronic constipation and irritable bowel syndrome. Peptides, 31(8), 1426-1433. https://doi.org/10.1016/j.peptides. 2010.05.003

Maguire, J. D. (1962). Speed of germination aid in selection and evaluation for seedling and vigour. Crop Science, 2(2), 176-177. https://doi.org/10.2135/cropsci1962.0011183X000200020033x

Malavolta, E., Vitti, G. C., \& Oliveira, S. A. (1997). Avaliação do estado nutricional das plantas princípios e aplicações (2nd ed.). Piracicaba, SP: Associação Brasileira para Pesquisa do Potássio e do Fosfato.

Martinotto, C., Paiva, R., Santos, B. R., Soares, F. P., Nogueira, R. C., \& Silva, A. A. N. (2007). Efeito da escarificação e luminosidade na germinação in vitro de sementes de cagaiteira (Eugenia dysenterica $\mathrm{DC}$.). Ciência e Agrotecnologia, 31(6), 1668-1671. https://doi.org/10.1590/S1413-70542007000600010

Melo, J. T., \& Haridasan, M. (2009). Respostas de mudas de cagaita (Eugenia dysenterica DC.) a doses de N, $P$, $K$, Ca e $\mathrm{Mg}$. Planaltina, DF: Embrapa Cerrados.

Morgado, I. F., Carneiro, J. G. A., Leles, P. S. S., \& Barroso, D. G. (2009). Resíduos agroindustriais prensados como substrato para a produção de mudas de cana-de-açúcar. Scientia Agricola, 57(4), 709-712. https://doi.org/10.1590/S0103-90162000000400017

Mota, C. S., Silva, F. G., Dornelles, P., Costa, A. C., Araujo, E. L. A., \& Mendes, G. C. (2016a). Use of physiological parameters to assess seedlings quality of Eugenia dysenterica DC. grown in different substrates. Australian Journal of Crop Science, 10(6), 842-851. https://doi.org/10.21475/ajcs.2016.10. 06.p7501

Mota, C. S., Silva, F. G., Dornelles, P., Freiberger, M. B., \& Mendes, G. C. (2016b). Growth, nutrition and quality of Pouteria garderiana (a. Dc.) Radlk. seedlings produced in organic substrates. Cerne, 22(4), 373-380. https://doi.org/10.1590/01047760201622042234

Neves, N. R., Oliva, M. A., Centeno, D. C., Costa, A. C., Ribas, R. F., \& Pereira, E. G. (2009). Photosynthesis and oxidative stress in the resting plant species Eugenia uniflora L. exposed to simulated acid rain and iron ore dust deposition: Potential use in environmental risk assessment. Science of the Total Environment, 407(1), 3740-3745. https://doi.org/10.1016/j.scitotenv.2009.02.035

Nietsche, S., Gonçalves, V. D., Pereira, M. C. T., Santos, F. A., Abreu, S. C., \& Mota, W. F. (2004). Tamanho da semente e substratos na germinação e crescimento inicial de mudas de cagaiteira. Ciência e Agrotecnologia, 28(6), 1321-1325. https://doi.org/10.1590/S1413-70542004000600014

Nogueira, R. J. M. C., Albuquerque, M. B., \& Silva Júnior, J. F. (2003). Efeito do substrato na emergência, crescimento e comportamento estomático em plantas de mangabeira. Revista Brasileira de Fruticultura, 25(1), 15-18. https://doi.org/10.1590/S0100-29452003000100006

Paiva Sobrinho, S., Luz, B., Silveira, T. L. S., Ramos, D., Neves, L. G., \& Barelli, M. A. A. (2010). Substratos na produção de mudas de três espécies arbóreas do cerrado. Revista Brasileira de Ciências Agrárias, 5(2), 238-243. https://doi.org/10.5039/agraria.v5i2a741 
Silva, E. A., Maruyama, W. I., Oliveira, A. C., \& Bardiviesso, D. M. (2009). Efeito de diferentes substratos na produção de mudas de mangabeira (Hancornia speciosa). Revista Brasileira de Fruticultura, 31(3), 925-929. https://doi.org/10.1590/S0100-29452009000300043

Silveira, C. E. S., Palhares, D., Pereira, L. A. R., Pereira, K. B. D., \& Silva, F. A. B. (2013). Strategies of plant establishment of two Cerrado species: Bysonima basiloba Juss. (Malpighiaceae) and Eugenia dysenterica Mart. ex DC (Myrtaceae). Plant Species Biology, 28(1), 130-137. https://doi.org/10.1111/j.1442-1984.2012. 00366.x

Souza, E. R. B., Carneiro, I. F., Naves, R. V., Borges, J. D., Leandro, W. M., \& Chaves, L. J. (2001). Emergência e crescimento de cagaita (Eugenia dysenterica DC.) em função do tipo e do volume de substratos. Pesquisa Agropecuária Tropical, 31(2), 89-95.

Souza, E. R. B., Naves, R. V., \& Oliveira, M. F. (2013). Início da produção de frutos de cagaiteira (Eugenia dysenterica DC) implantada em Goiânia, Goiás. Revista Brasileira de Fruticultura, 35(3), 906-909. https://doi.org/10.1590/S0100-29452013000300030

Souza, P. M., Sales, P. M., Simeoni, L. A., Silva, E. C., Silveira, D., \& Magalhães, P. O. (2012). Inhibitory activity of $\alpha$-amylase and $\alpha$-glucosidase by plant extracts from the Brazilian Cerrado. Planta Medica, 78(1), 393-399. https://doi.org/10.1055/s-0031-1280404

\section{Copyrights}

Copyright for this article is retained by the author(s), with first publication rights granted to the journal.

This is an open-access article distributed under the terms and conditions of the Creative Commons Attribution license (http://creativecommons.org/licenses/by/4.0/). 